\title{
Informatization, Micro-Innovation and Dynamic Competitive Advantage
}

\author{
Jiayu Chi \\ School of Business, Sun Yat-sen University, Guangzhou, China \\ Email: chijiayu@mail.sysu.edu.cn
}

How to cite this paper: Chi, J. Y. (2021). Informatization, Micro-Innovation and Dynamic Competitive Advantage. American Journal of Industrial and Business Management, 11, 846-858.

https://doi.org/10.4236/ajibm.2021.117052

Received: June 11, 2021

Accepted: July 23, 2021

Published: July 26, 2021

Copyright $\odot 2021$ by author(s) and Scientific Research Publishing Inc. This work is licensed under the Creative Commons Attribution International License (CC BY 4.0).

http://creativecommons.org/licenses/by/4.0/

\begin{abstract}
Based on the perspective of micro-innovation, this paper puts forward the formation mechanism model of dynamic competitive advantage to explain the formation mechanism of dynamic competitive advantage in super competitive environment and the internal mechanism of information technology helping enterprises obtain dynamic competitive advantage. The formation mechanism model of dynamic competitive advantage emphasizes that in the super competitive market environment, enterprises cannot continue to obtain long-term competitive advantage by monopolizing the scarce resources that cannot be imitated and replaced, and they need to improve their micro innovation ability and expand the influence of micro innovation through information technology, so as to obtain and maintain the competitive advantage through continuous micro-innovation.
\end{abstract}

\section{Keywords}

Dynamic Competitive Advantage, Dynamic Capabilities, Micro-Innovation, Information Technology

\section{Introduction}

"Why some enterprises can achieve better performance than other enterprises" has always been the core of strategic management research. Mainstream strategic management theories (including competitive strategy theory, resource-based theory and dynamic capability theory) have carried out extensive and in-depth discussion on this issue (Porter, 1980; Wernerfelt, 1984; Barney, 1991; Peteraf, 1993). However, with the rapid change of technology and consumer demand, a large number of new market entrants and alternative products have emerged, and the competition among enterprises has become increasingly fierce. It is difficult for enterprises to monopolize the resources that can bring them sustaina- 
ble competitive advantage for a long time. The premise assumption of many traditional theories has changed, which cannot fully explain the acquisition and maintenance of enterprise competitive advantage in the current highly dynamic market environment.

At the same time, in the context of knowledge economy and information economy, information technology (IT) has been rapidly developed and widely used in recent years, and its influence and importance on enterprises are increasing. At present, there are many researches on the relationship between information technology and competitive advantage (Hitt \& Brynjolfsson, 1996; Carr, 2003; Mata et al., 1995; Wade \& Hulland, 2004), but the research on the internal influence mechanism of information technology on competitive advantage in a highly dynamic environment is still very lacking.

Micro-innovation, as a hot spot in the theoretical and practical circles, is closely related to information technology and competitive advantage of enterprises. Information technology can not only provide sufficient information and a unified technological innovation platform for the micro-innovation activities of enterprises, and improve the micro-innovation capabilities of enterprises, but also help to copy the micro-innovation of enterprises to the entire enterprise quickly and at low cost, realize the maximization of micro-innovation value, and help the enterprise to obtain and maintain competitive advantage. Therefore, it will be a beneficial exploration to introduce micro-innovation into the research of the internal influence mechanism of information technology on competitive advantage.

This paper is structured as follows: 1) the literature review is in section 2, 2) the definitions and characteristics of dynamic competitive advantage and micro-innovation are discussed in section 3,3) the formation mechanism model of dynamic competitive advantage is proposed in section 4,4 ) the management implications are discussed in section 5,5$)$ theoretical contribution and further research areas are presented in section 6.

\section{Literature Review}

\subsection{IT and Competitive Advantage}

Whether IT can bring a competitive advantage to enterprises has always been the focus of attention and debate in the theoretical and practical circles. Although many scholars believe that IT can help companies gain a competitive advantage, the voice of doubt has never ceased. The research results of Hitt and Brynjolfsson show that the IT investment of a company is necessary to maintain a competitive balance with competitors, but it does not necessarily bring excess profit margins to the company, so it may not necessarily bring a competitive advantage to the company (Hitt \& Brynjolfsson, 1996). The paper “IT Doesn't Matter" by Professor Carr of Harvard University triggered a big discussion about "whether IT can bring enterprises a competitive advantage". He believes that IT is already a standardized commodity, and innovative applications of IT will be 
quickly imitated and copied, thus failing to bring sustainable competitive advantages to enterprises (Carr, 2003).

The existing research on the relationship between IT and competitive advantage is mainly carried out with the development of competitive strategy theory, resource-based theory and dynamic capability theory.

Porter's competitive strategy theory believes that the external market structure of the company and the company's positioning in a specific industry determine the company's competitive advantage. Companies can use IT to improve their bargaining power with upstream and downstream companies, enhance their ability to use opportunities and resist threats, and build industry entry barriers to gain and maintain competitive advantages (Porter, 1980). However, the theory of competitive strategy only considers the external factors of the enterprise, but ignores the internal factors of the enterprise, so it cannot explain why many enterprises in the same industry, even though they have the same information system, have great differences in the current industry status and competitive advantage.

The resource-based theory focuses on the inside of the enterprise and pays more attention to the nature of the enterprise's own resources. It believes that the competitiveness of an organization comes from the heterogeneous resources of the organization itself (such as management skills, organizational processes, conventions and knowledge, etc.). These heterogeneities resources can bring sustainable competitive advantages to enterprises (Barney, 1991). According to the resource-based theory, due to the non-scarcity and imitability of IT itself, IT is only a necessary condition for enterprises to obtain a competitive advantage. However, due to the close integration of IT with business strategy, organization, process, etc., and IT's integration of internal and external resources of the enterprise, it has path dependence and social complexity, which is difficult to imitate, so it can help enterprises to obtain sustainable competitive advantages. Mata et al. used the resource-based theory to analyze the impact of IT on sustainable competitive advantage, and believed that the IT management skills formed by enterprises in the long-term application of IT are difficult to imitate, so they can become a source of sustainable competitive advantage (Mata et al., 1995). However, since IT investments are mostly sunk costs, the information technology and information systems of enterprises have a certain degree of stability. Under the rapidly changing technology and market environment, the competitive advantages brought by information technology may quickly turn into competitive disadvantages. For example, the business processes and management methods solidified by the information system may no longer adapt to the current environment. Therefore, the resource-based theory cannot explain the problem of how to obtain competitive advantage in a dynamic environment.

The dynamic capability theory proposed by Teece et al. believes that the rapid integration, establishment and reconstruction of internal and external resources and capabilities possessed by enterprises to adapt to the rapidly changing external environment is more helpful for enterprises to obtain sustainable competi- 
tive advantages (Teece et al., 1997). With the development of the dynamic capability theory, more and more scholars believe that IT resources alone cannot bring sustainable competitive advantages to enterprises, but the "IT capabilities" (that is, the ability to mobilize and deploy IT resources) possessed by enterprises It is the decisive factor that IT helps companies gain long-term competitive advantage. Ross et al. first proposed the concept of IT capability and defined IT capability as "the ability to control IT-related costs and influence organizational goals through the implementation of IT" (Ross et al., 1996). Wade and others believe that IT capability forms a complex chain of assets and capabilities by influencing the competitive activities of enterprises, and ultimately brings sustainable competitive advantage to enterprises (Wade \& Hulland, 2004). Dynamic capability theory provides a good way to solve the problem of competitive advantage acquisition in the rapidly changing environment. However, as dynamic capability is a very complex and abstract concept, the current research has just started.

\subsection{Innovation and Competitive Advantage}

Schumpeter first proposed the concept of "innovation" in 1912. He believed that innovation is the establishment of a new production function, or a new combination of production factors by entrepreneurs. The innovative activities of enterprises are an important driving force and the most fundamental of economic growth mechanism (Schumpeter, 1912).

Many studies have found that successful companies are often companies that are good at innovation. Therefore, scholars are increasingly concerned about the relationship between innovation and corporate competitive advantage (Pouder \& John, 1996). Through innovation activities, companies can generate some specific assets and capabilities that are difficult to imitate by competitors (Schumpeter, 1934). Enterprises can obtain temporary monopoly power through innovation, and thus obtain excess returns, that is, "Schumpeterian rent", thereby gaining temporary competitive advantage (Schumpeter, 1934).

In a static environment, companies can rely on unique resources and prevent other companies from imitating to maintain a competitive advantage for a long time. However, in a dynamic environment, due to the effects and changes of many factors, such as supply and demand and competition, are in a process of violent and non-continuous nonlinear turbulence, the business decision-making and foresight ability of enterprises is severely weakened. At the same time, the rapid development of information technology has greatly enhanced the imitation ability of enterprises. Therefore, it is more important for enterprises to have a dynamic innovation capability to maintain their competitive advantage. Many scholars have conducted in-depth discussions on enterprise innovation capabilities (Lawson \& Samson, 2001; Romijn \& Albaladejo, 2002).

\subsection{Micro-Innovation}

Garcia and Calantone (2002) divided innovation into fundamental innovation, 
moderate innovation and incremental innovation according to the degree of innovation. Among them, incremental innovation is defined as products that provide new features, benefits or upgrades for current technologies in the current market. Zhou Hongwei (2010) proposed a concept similar to incremental innovation named "micro-innovation". Zhou Hongwei defined micro-innovation as "your product can be imperfect, but as long as it can touch the sweetest point in the user's heart and solve a problem. This kind of single-point breakthrough is called micro-innovation". Micro-innovation has not only become an innovative trend but has also been regarded as a kind of creative thinking (Zhao, 2012).

In summary, previous studies have obtained many valuable conclusions, but there are also the following problems:

1) Existing research cannot fully explain the acquisition and maintenance of corporate competitive advantage in the current fast-changing and fiercely competitive environment.

2) Although there has been a lot of research on the relationship between IT and competitive advantage and the relationship between innovation and corporate competitive advantage, the research on the relationship between IT and innovation, especially for IT, innovation and corporate competitive advantage relationship research is still very lacking.

3) At present, the research on micro-innovation has just started. Not only has it not formed a strict and clear definition of micro-innovation, but there are still many disputes about the concept of micro-innovation.

Therefore, from the perspective of IT and innovation, this paper analyzes the formation mechanism of corporate competitive advantage in a rapidly changing and fiercely competitive environment, and further discusses the relationship among IT, micro-innovation, and dynamic competition advantage.

\section{Micro-Innovation and Dynamic Competitive Advantage}

\subsection{Definition of Dynamic Competitive Advantage}

Aveni \& Gunther (1994) found that the formation and loss of corporate competitive advantages in many industries are very fast. He called this phenomenon super-competition. In a hyper-competitive environment, the competitive advantages of enterprises are not sustainable. With the emergence of new technologies, changes in user preferences, and changes in government policies, unimitable resources and capabilities and first-mover advantages will become worthless. Therefore, enterprises will lose their original competitive advantages.

In a hyper-competitive environment, in order to obtain and maintain a competitive advantage, companies should be sensitive to changes in the external environment (including technology, market, competitors, policies, etc.), and destroy their competitive advantages in the industry through innovative activities sources (including the company's own competitive advantages), and continuously create a series of new competitive advantages, so as to ensure that the company is in an advantageous position in the competition.

In this paper, the dynamic competitive advantage is defined as "the possibil- 
ity of businesses in a dominant position in a dynamic competition." The higher the frequency that an enterprise is in a dominant position in dynamic competition, the greater its dynamic competitive advantage. In the process of competing with competitors, companies with dynamic competitive advantages, although they may temporarily lag behind, can always regain their competitive advantages through continuous reforms and innovations.

\subsection{Characteristics of Dynamic Competitive Advantage}

From the concept of dynamic competitive advantage, we can see that dynamic competitive advantage has some special properties:

- Sustainability. Dynamic competitive advantage does not mean that a company obtains a competitive advantage at a certain point of time, but a competitive advantage that the company can maintain over a long period of time.

- Dynamic. Dynamic competitive advantage develops dynamically and changes with time and the environment. Due to intensive competition among enterprises, the rank of enterprises will change intensively. Although companies with dynamic competitive advantages may temporarily lag behind in competition, they can keep up with the pace of environmental changes through continuous reform and innovation, and regain their competitive advantage.

- Interactivity. The dynamic competitive advantage of a company is a competitive advantage relative to its competitors. It depends seriously on the strategic choices of competitors and their responses to the company's competitive strategy. Competing companies will learn from and imitate each other, so it is highly interactive.

Table 1 shows the comparison of dynamic competitive advantage, temporary competitive advantage and continuous competitive advantage.

Through innovation activities, enterprises can obtain "Schumpeter rent" and temporary competitive advantages, but with the diffusion of innovation or changes in the environment, this temporary competitive advantage will disappear. By monopolizing certain scarce, valuable, difficult to imitate and substitute resources, companies can obtain "Ricardo rents" and long-term sustainable competitive advantages. However, with the gradual improvement of the production factor market, it is often difficult for companies to monopolize such heterogeneous strategic resources; at the same time, with the changes in technology and consumer demand and the emergence of alternative resources, the value of resources accumulated by companies in the past will be greatly reduced, and it will be difficult for companies to maintain their original competitive advantage through these resources.

The dynamic competitive advantage emphasizes that in a market where production factors are not scarce and can flow freely, companies need to be sensitive to changes in the external environment, and to obtain dynamic competitive advantages through continuous innovation. Although the innovation behavior of enterprises may be learned and imitated by competitors, the IT capabilities and 
Table 1. Comparison table of dynamic competitive advantage, temporary competitive advantage and continuous competitive advantage.

\begin{tabular}{llll}
\hline & $\begin{array}{l}\text { Temporary } \\
\text { competitive } \\
\text { advantage }\end{array}$ & $\begin{array}{l}\text { Continuous } \\
\text { competitive } \\
\text { advantage }\end{array}$ & $\begin{array}{l}\text { Dynamic } \\
\text { competitive } \\
\text { advantage }\end{array}$ \\
\hline $\begin{array}{l}\text { Imitability } \\
\begin{array}{l}\text { Strategic } \\
\text { interaction with } \\
\text { competitors }\end{array}\end{array}$ & Short-term & Long-term & $\begin{array}{l}\text { Long-term, but may } \\
\text { temporarily lag behind }\end{array}$ \\
\hline
\end{tabular}

* Source: Compiled by the author.

innovation capabilities cultivated by the enterprise in the process of obtaining and maintaining dynamic competitive advantages are difficult to imitate by competitors.

\subsection{Definition of Micro-Innovation}

This paper defines micro-innovation as "a kind of incremental innovation guided by the improvement of user experience and with the goal of obtaining dynamic competitive advantages of the enterprise". Micro-innovation can be either product, process, and technology innovation, or process and management innovation.

Although both micro-innovation and incremental innovation are incremental innovations based on small improvements, their difference lies in the following two aspects:

1) Micro-innovation puts more emphasis on focusing this small improvement on the user experience. For example, Weibo and blog are the same in function and technology, but Weibo has made two minor adjustments to blogs. The first is based on greater portability for a good mobile communication platform. The second is to limit the number of words sent to 140 words to improve readability. These two adjustments make communication between users more efficient and faster.

2) Although micro-innovation is a kind of incremental innovation based on small improvements, it aims to obtain dynamic competitive advantages of enterprises. The combination of a large number of micro-innovations will change from quantitative to qualitative, which will have an impact on the original dominant design, thereby achieving disruptive innovation. For example, when the printer was first invented, the printed characters consist of many small dots, which are completely incomparable with the prints produced by exquisite printing machines, and the printing speed is very slow. However, after years of continuous improvement of micro-innovation, printers are now widely used, entered businesses and families, and had a disruptive impact on the printing industry. 


\section{Formation Mechanism Model of Dynamic Competitive Advantage}

\subsection{Definition of Basic Concepts}

1) IT capability: "the ability of an enterprise to mobilize and deploy IT-based resources” (Bharadwaj, 2000).

2) Dynamic competitive advantage: "the possibility of an enterprise in a competitive position".

3) Micro-innovation: "an incremental innovation guided by the improvement of user experience and with the goal of gaining enterprise dynamic competitive advantages".

\subsection{Formation Mechanism Model of Dynamic Competitive Advantage Based on IT Capability and Micro-Innovation}

The formation mechanism model of dynamic competitive advantage is shown in Figure 1.

Higher IT capabilities can not only improve the company's sensitivity to changes in the external environment (including customer needs, markets, technology, and competitors, etc.), and help companies obtain more and better information related to micro-innovation, but also It can build a good micro-innovation platform and environment for enterprises and improve their micro-innovation capabilities. McAfee and Brynjolfsson (2008) believe that IT can build a unified technology platform for enterprises and act as a creative catalyst in innovation, which helps people generate creativity. Therefore, this paper believes that IT capabilities have a significant positive impact on the micro-innovation capabilities of enterprises.

Many scholars' studies have also shown that innovation capability has a significant positive impact on the competitive advantage of enterprises (Christensen, 1997; Chesbrough, 2006). Micro-innovation capability is a new capability concept proposed based on capability theory. It can help enterprises produce continuous micro-innovation, and is particularly important for obtaining dynamic competitive advantages of enterprises. Therefore, this paper argues that micro-innovation capabilities have a significant positive impact on the dynamic competitive advantage of enterprises.

The research of McAfee and Brynjolfsson found that the digitization of business processes makes it easy for companies to carry out process innovations and

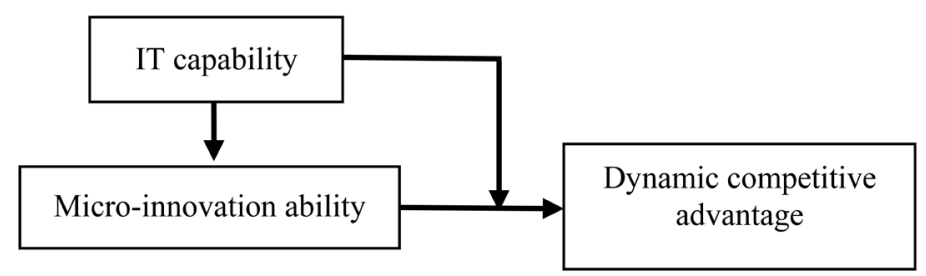

Figure 1. The formation mechanism model of dynamic competitive advantage. 
to quickly replicate the innovation model across the company, thus making the value of innovation doubled and helping companies gain competitive advantage (McAfee \& Brynjolfsson, 2008). Similarly, companies with higher IT capabilities can replicate corporate micro-innovations to the entire enterprise at a faster speed and lower cost, and allocate corporate resources more effectively, thereby maximize the value of micro-innovation, and bring greater dynamic competitive advantage to enterprises. Therefore, this paper argues that IT capability plays a positive moderating effect in the process of the impact of micro-innovation capability on the dynamic competitive advantage of enterprises, that is, the stronger the IT capability of enterprises, the greater the positive impact of micro-innovation capability on the dynamic competitive advantage of enterprises.

\section{Management Implications}

This paper proposes the formation mechanism model of enterprise dynamic competitive advantage, which can not only explain the principle of enterprise obtaining dynamic competitive advantage in a highly dynamic environment, but also guide enterprise management practice and help enterprise obtain dynamic competitive advantage.

\subsection{For Start-ups and Small and Medium-Sized Enterprises}

For start-ups and small and medium-sized enterprises, their own IT capabilities are relatively poor. These enterprises can acquire the IT resources and IT capabilities that companies desperately need by adopting cloud computing and IT outsourcing. At the same time, since these small companies are at a disadvantage compared with large companies in terms of capital, technology, brand, production capacity, management experience, and marketing network scale, these small companies should focus on low-end consumers, deeply cultivate emerging and fast-growing markets that neglected by large companies. Although in the beginning, it often faces the problems of small market, low profit, high risk and low quality, with the continuous trial and error, and rapid micro-innovation is likely to change from quantitative change to qualitative change, and even bring disruptive innovation to these enterprises.

Pinduoduo is a typical representative of successful startups by micro-innovation. It took only 6 years to develop from zero to a gathering of 800 million annual active buyers and 5 million active merchants. According to its 2020 full-year financial report, Pinduoduo is the second largest e-commerce platform in China with a value of RMB 1.67 trillion annual transactions. At the beginning of the founding of pinduoduo, the domestic B2C retail e-commerce market was a competitive Red Sea market, where Taobao and Jingdong were the top two, and there were many other competitors such as Amazon, Dangdang, No.1 store, and Vipshop.

The start-up Pinduoduo focuses on low-tier cities that are ignored by mainstream e-commerce platforms. It uses WeChat as its entrance and uses WeChat 
platform's WeChat payment, WeChat applets, WeChat red envelopes and other information technologies to carry out a large number of micro-innovations and successfully integrate e-commerce among the social platforms. In the process of Pinduoduo's rapid development and growth, information technology has played a very important role in supporting and leading. Cloud computing technology satisfies the needs of Pinduoduo's rapid expansion, and artificial intelligence and big data technology have now become Pinduoduo's core competitiveness.

\subsection{For Large Enterprises}

For large enterprises, they have made a lot of investment in IT, and have more IT resources and higher IT capabilities, which provides a solid platform and foundation for the company's innovation and future development. But large enterprises are prone to suffer from the "big enterprise disease" of bloated institutions, unclear responsibilities, poor information, slow decision-making and actions, and contentment with the status quo. These companies need to use information technology and information systems to help them optimize business processes, sensitively perceive changes in the internal and external environment of the company, quickly transmit information and make rapid decisions and actions, and help them rejuvenate through digital transformation. In addition, large companies should use information technology to vigorously promote micro-innovation, and quickly replicate micro-innovation across the company, so that the value of micro-innovation is doubled and helps companies gain a competitive advantage.

Tencent is a typical representative of large companies that gain competitive advantage through micro-innovation. Although many people think Tencent is the "king of copycats" and many of Tencent's products indeed imitated and copied from other companies' products, why does Tencent always succeed in surpass the imitated products?

The key to Tencent's success is its strong micro-innovation capabilities and IT capabilities. Tencent pays special attention to micro-innovation based on user experience. Tencent's early flagship product QQ has carried out many micro-innovations, such as dragging QQ friends to the computer desktop to make chat more convenient; QQ's file transfer speed faster than MSN. WeChat is also a product of micro-innovation. For the micro-innovation cases of WeChat, please refer to Luo Zhongwei's papers published in 2015 (Luo \& Jiao, 2015).

At the same time, Tencent's founder and CEO Ma Huateng graduated with a major in computer science, which made Tencent attach great importance to the cultivation and construction of the company's IT capabilities from the very beginning. At present, Tencent has accumulated strong IT capabilities in cloud computing, big data, mobile payment, security and other fields. Tencent's strong IT capabilities promoted its micro-innovation capabilities, and Tencent relied on a large number of user experience-centric micro-innovations to help it gain a position of dynamic competitive advantage. 


\section{Theoretical Contribution and Further Research Directions}

Different from resource-based view's assumption that scarce, valuable, hard-toimitate and substitute resources can bring sustainable competitive advantages for enterprises, the formation mechanism model of dynamic competitive advantage emphasizes that in a non-scarce market where resources can flow freely, enterprises are unable to obtain unique scarce resources and capabilities that cannot be imitated and replaced. In order to maintain a company's competitive advantage, the company needs to obtain dynamic competitive advantage through continuous micro-innovation.

The theoretical contributions and innovations of this paper are as follows:

1) This paper analyzes the concept of dynamic competitive advantage and its difference from temporary competitive advantage and sustained competitive advantage, and proposes the formation mechanism model of dynamic competitive advantage. From the perspective of IT capability and innovation, this paper analyzes the formation mechanism of dynamic competitive advantage of enterprises in the rapidly changing and highly competitive environment, which makes up for the lack of existing research on competitive advantage in dynamic environment.

2) This paper reviews the existing discussions on micro-innovation, defines the concept of micro-innovation, analyzes the differences between micro-innovation and incremental innovation, and analyzes the relationship among information technology, micro-innovation and enterprise dynamic competitive advantage, which enriches and improves the existing research on micro-innovation.

The limitations and further research directions of paper include:

1) This paper only provides a basic theoretical framework for studying the dynamic relationship among IT, micro-innovation and enterprise dynamic competitive advantage. More researches are needed to enrich and improve the theoretical framework.

2) This paper only proposed a theoretical model, more case studies and empirical studies can be conducted in the future to verify the theoretical model.

\section{Conflicts of Interest}

The author declares no conflicts of interest regarding the publication of this paper.

\section{References}

Aveni. D, R., \& Gunther, R. (1994). Hypercompetition: Managing the Dynamics of Strategic Maneuvering. New York: The Free Press.

Barney, J. B. (1991). Firm Resource and Sustained Competitive Advantage. Journal of Management, 17, 99-120. https://doi.org/10.1177\%2F014920639101700108

Bharadwaj, A. S. (2000). A Resource-Based Perspective on Information Technology Capability and Firm Performance: An Empirical Investigation. MIS Quarterly, 24, 169-196. https://doi.org/10.2307/3250983 
Carr, N. G. (2003). IT Doesn't Matter. Harvard Business Review, 81, 41-49.

Chesbrough, H. W. (2006). Open Innovation: The New Imperative for Creating and Profiting from Technology. Academy of Management Perspectives, 20, 86-88. https://doi.org/10.5465/amp.2006.20591014

Christensen, C. M. (1997). The Innovator's Dilemma. Harvard Business School Press.

Garcia, R., \& Calantone, R. (2002). A Critical Look at Technological Innovation Typology and Innovativeness Terminology: A Literature Review. Journal of Product Innovation Management, 19, 110-132. https://doi.org/10.1111/1540-5885.1920110

Hitt, L. M., \& Brynjolfsson, E. (1996). Productivity, Business Profitability, and Consumer Surplus: Three Different Measures of Information Technology Value. MIS Quarterly, 20, 121-142. https://doi.org/10.2307/249475

Lawson, B., \& Samson, D. (2001). Developing Innovation Capability in Organisations: A Dynamic Capabilities Approach. International Journal of Innovation Management, 5, 377-400. https://doi.org/10.1142/S1363919601000427

Luo, Z., Jiao, H., \& Xu, Y. (2015). Tencent Wechat's Micro-Innovation of Integration and Iteration under Technical Paradigm Transformation. China Economist, No. 5, 106-122.

Mata, F. J., Fuerst, W. L., \& Barney, J. B. (1995). Information Technology and Sustained Competitive Advantage: A Resource-Based Analysis. MIS Quarterly, 19, 487-505. https://doi.org/10.2307/249630

Mcafee, A., \& Brynjolfsson, E. (2008). Investing in the IT that Makes a Competitive Difference. Harvard Business Review, 33, 98-107.

Peteraf, M. A. (1993). The Cornerstones of Competitive Advantage: A Resource-Based View. Strategic Management Journal, 14, 179-191. https://doi.org/10.1002/smj.4250140303

Porter, M. E. (1980). Competitive Strategy: Techniques for Analyzing Industries and Competitors (pp. 86-87). New York: Free Press.

Pouder, R., \& St. John, C. H. (1996). Hot Spots and Blind Spots: Geographical Clusters of Firms and Innovation. The Academy of Management Review, 21, 1192-1225. https://doi.org/10.5465/amr.1996.9704071867

Romijn, H., \& Albaladejo, M. (2002). Determinants of Innovation Capability in Small Electronics and Software Firms in Southeast England. Research Policy, 31, 1053-1067. https://doi.org/10.1016/S0048-7333(01)00176-7

Ross, J. W., Beath, C. M., \& Goodhue, D. L. (1996). Develop Long-Term Competitiveness through IT Assets. Sloan Management Review, 38, 31-42.

Schumpeter, J. A. (1912). The Theory of Economic Development. Cambridge: Harvard University Press.

Schumpeter, J. A. (1934). The Theory of Economic Development: An Inquiry into Profits, Capital, Credit, Interest and the Business Cycle. Cambridge: Harvard University Press.

Teece, D. J., Pisano, G., \& Shuen, A. (2009). Dynamic Capabilities and Strategic Management. Strategic Management Journal, 18, 509-533. https://doi.org/10.1002/(SICI)1097-0266(199708)18:7\%3C509::AID-SMJ882\%3E3.0.C $\mathrm{O} ; 2-\mathrm{Z}$

Wade, M. R., \& Hulland, J. (2004). The Resource-Based View and Information Systems Research: Review, Extension, and Suggestions for Future Research. MIS Quarterly, 28, 107-142. https://doi.org/10.2307/25148626

Wernerfelt, B. (1984). A Resource-Based View of the Firm. Strategic Management Journal, 5, 171-180. https://doi.org/10.1002/smj.4250050207 
Zhao, F. C. (2012). A Study on the Characteristics and Capability Enhancement Strategy of Enterprise Micro-Innovation. Studies in Science of Science, 30, 1579-1583.

Zhou, H. Y. (2010). Micro-Innovation. Entrepreneurship in Science and Technology, No. 12, 39-39. 